\title{
Faktor yang Mempengaruhi Konsumsi Daging Kuda pada Rumah Tangga di Kecamatan Doloksanggul Kabupaten Humbang Hasundutan Sumatera Utara
}

\author{
Analysis of Factors Affecting Consumption of Horse Meat in Households in Doloksanggul \\ District, Humbang Hasundutan District, North Sumatra
}

\author{
I. Sihite ${ }^{1}$, S. Kadarsih ${ }^{2}$, dan Dwatmadji ${ }^{2}$ \\ Jurusan Peternakan, Fakultas Pertanian, Universitas Bengkulu \\ Email : imeldasihite@yahoo.com
}

\begin{abstract}
This study aimed to determine the factors that affect consumption of horse meat in households in Doloksanggul sub-district, Humbang Hasundutan Regency, North Sumatra. Where this study looks at whether the factors of gender, age, education, occupation, income, number of family members, the price of horse meat, substitute goods, reasons for consuming horse meat, ethnicity, and taste affect the consumption of horse meat. The method of determining research subjects was determined by purposive sampling (intentional) with a total sample of 99 households (KK). The data analysis method used was multiple linear regression which was discussed descriptively. The results of multiple linear regression showed that the variables of age, education, income, gender, occupation, number of members, substitution goods and tastes had a significant effect on consumption of horse meat, while the tribal variables and reasons negatively affected the consumption of horse meat, where $p<0$, 05. Based on the F test, where F arithmetic was 1.899 smaller than F table which was 16.054 it can be concluded that sex, age, education, occupation, income, price, number of members, substitute goods, ethnicity, reasons and tastes had a significant effects on consumption of horse meat.
\end{abstract}

Key words: horse meat, horse meat consumption

\begin{abstract}
ABSTRAK
Penelitian ini bertujuan untuk mengetahui faktor yang mempengaruhi konsumsi daging kuda pada rumah tangga di kecamatan Doloksanggul Kabupaten Humbang Hasundutan Sumatera utara. Dimana penelitian ini melihat apakah faktor jenis kelamin, umur, pendidikan, pekerjaan, pendapatan, jumlah anggota keluarga, harga daging kuda, barang subsitusi, alasan mengkonsumsi daging kuda, suku, dan selera berpengaruh terhadap konsumsi daging kuda. Metode penentuan subjek penelitian ditentukan secara purposive sampling (disengaja) dengan jumlah sampel sebanyak 99 kepala keluarga (KK). Metode analisis data yang digunakan yaitu regresi linier berganda yang dibahas secara deskriptif. Hasil regresi linear berganda menunjukkan bahwa variabel umur, pendidikan, pendapatan, jenis kelamin, pekerjaan, jumlah anggota, barang subsitusi dan selera berpengaruh signifikan terhadap konsumsi daging kuda, sedangkan variabel suku dan alasan berpengaruh secara negatif terhadap konsumsi daging kuda, dimana $\mathrm{p}<0,05$. Berdasarkan uji $\mathrm{F}$, dimana $\mathrm{F}$ hitung sebesar 1,899 lebih kecil dari F tabel yakni 16,054 maka dapat disimpulkan bahwa secara bersama-sama jenis kelamin, umur, pendidikan, pekerjaan, pendapatan, harga, jumlah anggota, barang subsitusi, suku, alasan dan selera berpengaruh signifikan terhadap konsumsi daging kuda.
\end{abstract}

Kata Kunci: daging kuda, konsumsi daging kuda

\section{PENDAHULUAN}

Pertumbuhan penduduk, urbanisasi, peningkatan pendapatan masyarakat akan berpengaruh pada peningkatan permintaan bahan pangan asal ternak bahkan di negara negara berkembang termasuk Indonesia diramalkan laju pertumbuhan permintaan ternak dan hasil ternak akan meningkat lebih pesat (Hadiyanto, 2007).

Daging adalah salah satu hasil ternak yang hampir tidak dapat dipisahkan dari kehidupan manusia. Selain penganekaragaman sumber pangan, daging dapat menimbulkan kepuasan atau kenikmatan bagi yang memakannya karena 
kandungan gizinya lengkap, sehingga keseimbangan gizi untuk hidup dapat terpenuhi (Soeparno, 1998).

Salah satu jenis ternak yang perlu mendapatkan perhatian dan potensial untuk produksi daging adalah ternak kuda. Ternak kuda dapat menjadi alternatif penyedia daging dan mempunyai potensi yang cukup besar sebagai salahsatu sumber pangan yang mempunyai kandungan protein yang sangat tinggi. Potensi ternak kuda secara teknis tidak jauh berbeda dengan sapi, dimana karkas ternak kuda mencapai $125 \mathrm{~kg}$, dengan jeroan mencapai 20\% dari karkas dibandingkan sapi yang mencapai angka ratarata 156,4 kg (Kadir, 2011).

Ternak kuda memiliki kegunaan di masyarakat terutama digunakan sebagai tenaga kerja, sarana transportasi, olahraga dan untuk rekreasi.Selain itu ternak kuda juga memiliki potensi yang sangat besar dalam mendukung pariwisata, hal tersebut disebabkan karena ternak kuda memiliki nilai estetika yang tinggi untuk menarik wisatawan (Tim Karya Tani Mandiri, 2010).

Daging kuda sendiri digunakan sebagai bahan makanan manusia semenjak hewan tersebut diperlakukan sebagai hewan buruan. Sampai sekarang pemanfaatan daging kuda sebagai bahan makanan masih terdapat di beberapa penjuru dunia, termasuk di beberapa tempat di Indonesia. Disamping dagingnya, air susu kuda juga dipakai sebagai sumber makanan (Parakkasi, 2006).

Kadir (2006) mengatakan bahwa daging kuda memiliki kelebihan tersendiri, dimana kadar lemaknya hanya $4,1 \%$ dibanding ternak sapi $14,0 \%$. Sedangkan kadar protein hewaninya hampir sama, yakni kuda $18,1 \%$ dan sapi $18,8 \%$. Selain itu, kandungan lemak daging kuda yang relative rendah dan cita rasa yang manis.

Daging kuda rasanya agak manis, empuk, rendah lemak, dan berprotein tinggi yang bermanfaat sebagai sumber protein hewani. Protein hewani merupakan zat yang penting bagi tubuh manusia karena mengandung asam amino esensial yang berguna untuk membentuk antibodi serta pembentukan sel dan jaringan (Uptreninfo, 2012).

Dipandang dari segi nutrisi, daging adalah sumber asam amino yang sangat baik dan mineral - mineral tertentu. Daging organ seperti hati adalah sumber vitamin A, B1 dan asam nikotinat yang baik. Daging adalah sumber utama zat - zat makanan yang dibutuhkan untuk kesehatan manusia yang mengonsumsinya (Lawrie, 2003).

Daging kuda memiliki banyak khasiat, salah satunya adalah untuk menambah stamina dan gairah. Di luar itu, bisa juga untuk membantu mengatasi risiko asam urat, rematik, kencing manis, asma sampai gatal eksim. Karena kuda termasuk binatang yang suka bergerak, kolesterolnya pun menjadi sangat rendah (Hotabilatdur et al., 2013).

Hikmah (2003) mengatakan bahwa daging kuda mempunyai kandungan protein yang tinggi $(19,72 \%)$ dengan kandungan lemak yang rendah (4,84\%). Purba (2012) menambahkan bahwa pemanfaatan kuda sebagai penghasil daging masih sangat jarang dijumpai. Padahal dapat dilihat dari kandungan daging kuda bahwa daging kuda sangat berpotensi sebagai sumber protein bagi konsumsi masyarakat, sehingga permintaan daging kuda cenderung tidak stabil. Seperti terlihat pada Tabel 1 :

Tabel 1. Konsumsi daging kuda di Kab. Humbang Hasundutan

\begin{tabular}{ccc}
\hline No & Tahun & $\begin{array}{c}\text { Jumlah Konsumsi } \\
\text { Daging Kuda }(\mathrm{kg})\end{array}$ \\
\hline 1 & 2010 & 32.310 \\
2 & 2011 & 49.500 \\
3 & 2012 & 50.430 \\
4 & 2013 & 34.485 \\
5 & 2014 & 23.400 \\
6 & 2015 & 24.150 \\
\hline
\end{tabular}

Sumber : Dinas Peternakan dan Perikanan Kabupaten Humbang Hasundutan, 2014

Penelitian ini bertujuan untuk mengetahui faktor-faktor yang mempengaruhi konsumsi daging kuda pada rumah tangga di kecamatan Dolok Sanggul 
kabupaten Humbang Hasundutan Sumatera Utara.

\section{METODE PENELITIAN}

Penelitian ini dilaksanakan pada 07 April sampai 07 Mei tahun 2016 dengan lokasi di Kecamatan Doloksanggul Kabupaten Humbang Hasundutan Sumatera utara. Metode yang digunakan pada penelitian ini metode survey, yaitu dengan melakukan pendekatan langsung terhadap responden di Kecamatan Dolok Sanggul Kabupaten Humbang Hasundutan Sumatera utara.

Lokasi dipilih secara purposive sampling (disengaja), yaitu masyarakat yang mengkonsumsi daging kuda di Kecamatan Dolok Sanggul Kabupaten Humbang Hasundutan Sumatera utara. Melihat jumlah populasi yang besar, maka pada penelitian ini dilakukan pengambilan sampel. Penentuan jumlah sampel yang digunakan yaitu menggunakan rumus Slovin dalam Riduwan (2005) maka diperoleh jumlah responden sebanyak 99 kepala keluarga (KK) yang mengkonsumsi daging kuda.

Data yang diperoleh diolah dengan menggunakan Regresi Linear Berganda melalui program komputer SPSS 16 yang dibahas secara deskriptif. Dengan persamaan dari Regresi Berganda sebagai

$\mathrm{Y}=\mathrm{b}_{0}+\mathrm{b}_{1} \mathrm{X}_{1}+\mathrm{b}_{2} \mathrm{X}_{2}+\mathrm{b}_{3} \mathrm{X}_{3}+\mathrm{b}_{4} \mathrm{X}_{4}+\mathrm{b}_{5} \mathrm{X}_{5}+\mathrm{b}_{6} \mathrm{X}_{6}+\mathrm{b}_{7} \mathrm{X}_{7}+$ $\mathrm{b}_{8} \mathrm{X}_{8}+\mathrm{b} 9 \mathrm{X} 9+\mathrm{b}_{10} \mathrm{X}_{10}+\mathrm{b}_{11} \mathrm{X}_{11}+\mathrm{e}$

Dimana :

$\mathrm{Y}=$ Konsumsi daging kuda $(\mathrm{Kg} / \mathrm{Bulan})$

bo $=$ Konstanta

$b_{1} b_{2}, b_{3} b_{4}, b_{5}, b_{6} b_{7}, b_{8}, b_{9} b_{10} b_{11}=$ Koefisien regresi parsial untuk $\mathrm{X}_{1,} \mathrm{X}_{2}, \mathrm{X}_{3}, \mathrm{X}_{4}, \mathrm{X}_{5}, \mathrm{X}_{6}, \mathrm{X}_{7}, \mathrm{X}_{8}, \mathrm{X}_{9}, \mathrm{X}_{10} \mathrm{X}_{11}$

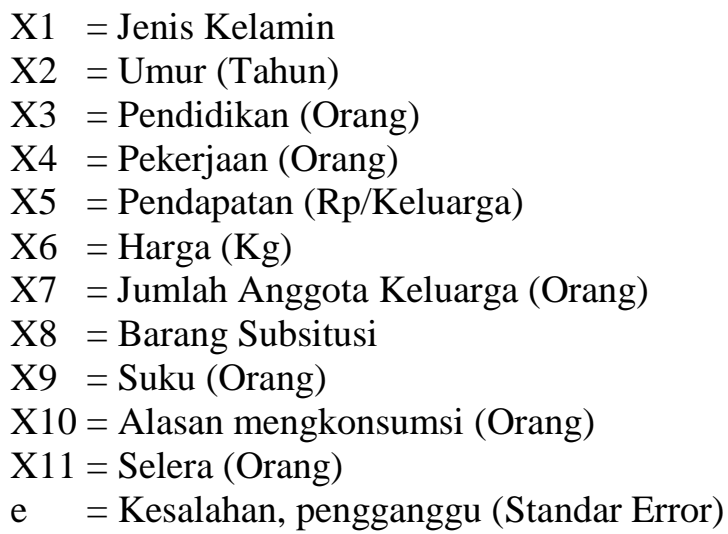

\section{HASIL DAN PEMBAHASAN}

\section{Gambaran daerah penelitian}

Doloksanggul adalah sebuah kecamatan di Kabupaten Humbang Hasundutan Sumatera Utara, Indonesia. Doloksanggul merupakan ibu kota Kabupaten Humbang Hasundutan, dengan luas Wilayah 20.930 Ha, Kecamatan Dolok Sanggul terdiri dari 1 Kelurahan dan 27 Desa dan 93 Dusun dengan suhu udara berkisar antara $18^{0} \mathrm{C}-30^{\circ} \mathrm{C}$. Seperti layaknya daerah tropis lainnya, Kecamatan Doloksanggul Humbang Hasundutan mengalami dua musim yaitu hujan dan kemarau. Selama tahun 2011 hujan cenderung lebih sering terjadi di Humbang Hasundutan, dimana tercatat bahwa hujan terjadi sebanyak 208 hari dengan rata - rata curah hujan mencapai 228,76 $\mathrm{mm}$ setiap bulannya. Wilayah kecamatan Doloksanggul berada di jajaran Bukit Barisan, berada pada ketinggian $1.200-1.400$ meter diatas permukaan laut (mdpl) (Humbahasnews, 2012).

Jumlah penduduk Kecamatan Doloksanggul dari tahun ke tahun mengalami peningkatan. Pada tahun 2010 jumlah penduduknya sebanyak 43.446 jiwa, dan tahun 2014 jumlah penduduk di Kecamatan Doloksanggul sebanyak 46.715 jiwa, dapat dilihat pada tabel 2 .

\section{Karakteristik responden}

Karakteristik responden merupakan gambaran dari keberadaan responden di tempat penelitian. Karakteristik tersebut dilihat berdasarkan tingkat yaitu kelamin, umur, pendidikan, pekerjaan, pendapatan, harga, jumlah anggota keluarga, barang subsitusi, suku, serta alasan mengkonsumsi daging kuda. 
Tabel 3. Karakteristik responden berdasarkan tingkat jenis kelamin, umur, pendidikan, pekerjaan, pendapatan dan harga di Kec. Doloksanggul Kab. Humbang Hasundutan Sumatera Utara

\begin{tabular}{|c|c|c|}
\hline Uraian & $\begin{array}{l}\text { Responden } \\
\text { (org) }\end{array}$ & $\begin{array}{c}\text { Persentase } \\
(\%)\end{array}$ \\
\hline \multicolumn{3}{|l|}{ Jenis kelamin } \\
\hline Pria & 63 & 63,63 \\
\hline Wanita & 36 & 36,36 \\
\hline Jumlah & 99 & 100 \\
\hline \multicolumn{3}{|l|}{ Umur } \\
\hline $27-35$ & 35 & 35,35 \\
\hline $36-45$ & 29 & 29,29 \\
\hline $46-55$ & 21 & 21,21 \\
\hline $56-65$ & 14 & 14,14 \\
\hline Jumlah & 99 & 100 \\
\hline \multicolumn{3}{|l|}{ Pendidikan } \\
\hline SD & 8 & 8,08 \\
\hline SMP & 13 & 13,13 \\
\hline SMA & 52 & 52,52 \\
\hline D3 & 9 & 9,09 \\
\hline S1 & 17 & 17,17 \\
\hline Jumlah & 99 & 100 \\
\hline \multicolumn{3}{|l|}{ Pekerjaan } \\
\hline $\begin{array}{l}\text { Ibu rumah } \\
\text { tangga }\end{array}$ & 3 & 3,03 \\
\hline Petani & 24 & 24,24 \\
\hline Wiraswasta & 48 & 48,48 \\
\hline PNS & 19 & 19,19 \\
\hline TNI & 3 & 3,03 \\
\hline Polisi & 2 & 2,02 \\
\hline Jumlah & 99 & 100 \\
\hline \multicolumn{3}{|l|}{ Pendapatan (Rp) } \\
\hline $2-3$ juta & 25 & 25,25 \\
\hline $3.1-4.1$ & 32 & 32,32 \\
\hline $4.2-5.2$ & 17 & 17,17 \\
\hline $5.3-6.3$ & 12 & 12,12 \\
\hline $6.4-7.4$ & 10 & 10,10 \\
\hline $7.5-8.5$ & 3 & 3,03 \\
\hline Jumlah & 99 & 100 \\
\hline \multicolumn{3}{|l|}{ Harga } \\
\hline Rp 120.000 & 66 & 66,66 \\
\hline Rp 125.000 & 19 & 19,19 \\
\hline Rp 128.000 & 9 & 9,09 \\
\hline Rp 130.000 & 5 & 5,05 \\
\hline Jumlah & 99 & 100 \\
\hline
\end{tabular}

Sumber : Data primer terolah, 2016
Tabel 4. Karakteristik responden berdasarkan jumlah anggota keluarga, barang subsitusi, suku, dan alasan mengkonsumsi daging kuda di Kec. Doloksanggul Kab. Humbang Hasundutan Sumatera Utara.

\begin{tabular}{lrr}
\hline Uraian & $\begin{array}{c}\text { Responden } \\
\text { (org) }\end{array}$ & $\begin{array}{r}\text { Persentase } \\
(\%)\end{array}$ \\
\hline Jumlah anggota & & \\
keluarga & 17 & 17,17 \\
$1-3$ & 72 & 72,72 \\
$4-6$ & 10 & 10,10 \\
$>7$ & 99 & 100 \\
\hline Jumlah & & \\
\hline Barang subsitusi & 25 & 25,25 \\
Daging ayam & 58 & 58,58 \\
Daging babi & 16 & 16,16 \\
Ikan & 99 & 100 \\
\hline Jumlah & & \\
\hline Suku & 6 & 6,06 \\
Jawa & 4 & 4,04 \\
Batak karo & 6 & 6,06 \\
Batak pakpak & 3 & 3,03 \\
Batak simalungun & 80 & 80,80 \\
Batak toba & 99 & 100 \\
\hline Jumlah & & \\
\hline Alasan & 2 & 2,02 \\
Coba - coba & 6 & 6,06 \\
Ajakan tetangga & 19 & 19,19 \\
Proteinnya tinggi & 13 & 13,13 \\
Meningkatkan suhu & & \\
tubuh dan stamina & 99 & 50,50 \\
Mengobati penyakit & 99 & 100 \\
Tradisi & & \\
\hline Jumlah & & \\
\hline Sumber : Data primer terolah, 2016 & & \\
\hline & & \\
\hline
\end{tabular}

Hasil regresi linear berganda menunjukkan bahwa variabel independen yaitu umur, pendidikan, pendapatan, jenis kelamin, pekerjaan, jumlah anggota, barang subsitusi dan selera berpengaruh positif terhadap variabel independen yaitu jumlah konsumsi daging kuda, sedangkan variabel independen yaitu suku dan alasan berpengaruh secara negatif terhadap konsumsi daging kuda. 
Tabel 5. Hasil uji regresi liner berganda faktor-faktor yang mempengaruhi konsumsi daging kuda di Kec. Doloksanggul Kab. Humbang Hasundutan Sumatera Utara

\begin{tabular}{lrrr}
\hline Variabel & Koefisien & $\mathrm{T}$ & Sig. \\
\hline Konstanta & $-0,8752$ & $-2,289$ & 0,024 \\
Jenis kelamin (X1) & 0,099 & 0,483 & 0,630 \\
Umur (X2) & 0,020 & 1,775 & 0,079 \\
Pendidikan (X3) & 0,170 & 1,468 & 0,146 \\
Pekerjaan (X4) & 0,194 & 1,221 & 0,225 \\
Pendapatan (X5) & 0,00000005075 & 5,073 & 0,000 \\
Harga (X6) & 0,000005046 & 1,626 & 0,107 \\
Jumlah anggota (X7) & 0,068 & 1,003 & 0,319 \\
Barang subsitusi (X8) & 0,039 & 0,267 & 0,790 \\
Suku (X9) & $-0,141$ & $-1,452$ & 0,150 \\
Alasan mengkonsumsi & $-0,049$ & $-0,630$ & 0,530 \\
(X10) & 0,411 & 2,945 & 0,004 \\
Selera (X11) & 0,670 & $\mathrm{~N}$ & 99 \\
R Square & 0,628 & siginifikan & $<0,05(5 \%)$ \\
Adj R Square & 16,054 & & \\
F & 0,000 & & \\
Sig & & & \\
\hline
\end{tabular}

Jenis kelamin memiliki nilai koefisien sebesar 0,099 yang berarti bahwa setiap terjadi peningkatan jenis kelamin akan menambah jumlah konsumsi sebesar 9,9\%. Variabel jenis kelamin tidak memiliki pengaruh terhadap konsumsi menunjukkan bahwa jenis kelamin bukan salah satu faktor yang mempengaruhi konsumsi daging kuda. Itu artinya responden tetap akan mengkonsumsi dalam jumlah yang sama meskipun jenis kelamin berbeda - berbeda.

Variabel umur memiliki nilai koefisien sebesar 0,020 yang berarti bahwa setiap terjadi peningkatan umur akan menambah jumlah konsumsi sebesar 2\%. Variabel umur tidak memiliki pengaruh terhadap konsumsi hal ini menunjukkan bahwa umur bukan salah satu faktor yang mempengaruhi untu mengkonsumsi daging kuda. Itu artinya responden tetap akan mengkonsumsi dalam jumlah yang sama meskipun umur berbeda. Hal ini sesuai dengan pendapat Hotabilatdur et al., 2013 bahwa tidak ada hubungan yang nyata antara variabel umur dengan permintaan daging kuda.

Variabel pekerjaan memiliki nilai koefisien sebesar 0,194 yang berarti bahwa setiap terjadi peningkatan umur akan menambah jumlah konsumsi sebesar 19,4\%.
Variabel pekerjaan tidak memiliki pengaruh terhadap konsumsi daging kuda hal ini menunjukkan bahwa pekerjaan bukan salah satu faktor yang mempengaruhi konsumsi daging kuda. Itu artinya responden tetap akan mengkonsumsi daging kuda dalam jumlah yang sama meskipun pekerjaan yang berbeda.

Variabel harga memiliki nilai koefisien sebesar 0,000005046 yang berarti bahwa setiap terjadi peningkatan harga akan menambah jumlah pembelian sebesar $0,005046 \%$. Variabel harga tidak memiliki pengaruh terhadap konsumsi menunjukkan bahwa harga bukan salah satu faktor yang mempengaruhi konsumsi daging kuda. Itu artinya responden tetap akan mengkonsumsi daging kuda dalam jumlah yang sama meskipun dengan harga yang berbeda.

Variabel suku memiliki nilai koefisien sebesar -0,141 yang berarti bahwa setiap terjadi peningkatan suku akan mengurangi jumlah konsumsi sebanyak $-14,1 \%$. Variabel suku tidak memiliki pengaruh terhadap konsumsi daging kuda hal ini menunjukkan bahwa suku bukan salah satu faktor yang mempengaruhi konsumsi. Responden tetap akan mengkonsumsi daging kuda dalam 
jumlah yang sama meskipun jenis suku berbeda.

Variabel alasan mengkonsusmsi daging kuda memiliki nilai koefisien sebesar -0,049 yang berarti bahwa setiap terjadinya perbedaan alasan akan mengurangi jumlah konsumsi sebanyak $-4,9 \%$. Variabel alasan tidak memiliki pengaruh terhadap konsusmsi menunjukkan bahwa alasan bukan salah satu faktor yang mempengaruhi konsumsi daging kuda. Itu artinya responden tetap akan mengkonsumsi daging kuda dalam jumlah yang sama meskipun alasan mengkonsusi yang berbeda.

Variabel pendidikan memiliki nilai variabel sebesar 0,170 yang berarti bahwa setiap terjadinya peningkatan pada pendidikan akan menambah nilai jumlah konsumsi sebanyak 17\%. Variabel pendidikan tidak memiliki pengaruh terhadap keputusan konsumsi daging kuda hal ini menunjukkan bahwa pendidikan bukan salah satu faktor yang mempengaruhi konsumsi. Responden tetap akan mengkonsumsi daging kuda dalam jumlah yang sama meskipun pendidikan berbeda.

Variabel pendapatan memiliki nilai koefisien sebesar 0,00000005075 yang berarti bahwa setiap terjadinya peningkatan pada pendapatan akan meningkatkan jumlah konsumsi sebanyak $5,075 \mathrm{e}^{-5}$. Nilai koefisien variabel pendapatan yang kecil menunjukkan jika variabel ini tidak memberikan pengaruh yang signifikan terhadap konsumsi daging kuda, meskipun harga daging kuda yang terbilang cukup mahal untuk semua kalangan namun hal ini membuat pendapatan tidak lagi memberi pengaruh yang besar dalam mengkonsumsi daging kuda.

Variabel jumlah anggota memiliki nilai koefisien sebesar 0,068 yang berarti bahwa setiap terjadinya peningkatan pada jumlah anggota akan meningkatkan jumlah konsumsi sebanyak 6,8\% Variabel jumlah anggota tidak memiliki pengaruh terhadap jumlah kosumsi daging hal ini menunjukkan bahwa jumlah anggota bukan salah satu faktor yang mempengaruhi jumlah konsumsi. Responden tetap akan mengkonsumsi daging kuda dalam jumlah yang sama meskipun jumlah anggota berbeda.

Variabel barang subsitusi memiliki nilai koefisien sebesar 0,039 yang berarti bahwa setiap terjadi peningkatan barang subsitusi akan menambah jumlah konsumsi sebesar 3,9\%. Variabel barang subsitusi tidak memiliki pengaruh terhadap jumlah konsumsi menunjukkan bahwa barang subsitusi bukan salah satu faktor yang mempengaruhi konsumsi daging kuda. Responden tetap akan mengkonsumsi sdalam jumlah yang sama meskipun barang subsitusi berbeda.

Variabel selera memiliki nilai koefisien sebesar 0,411 yang berarti bahwa setiap terjadinya peningkatan pada selera akan menambah jumlah jumlah konsumsi daging kuda sebesar 41,1\%. Variabel selera berpengaruh terhadap jumlah konsumsi hal ini menunjukkan bahwa selera merupakan salah satu faktor yang mempengaruhi jumlah konsumsi. Jadi, responden yang memiliki selera mengkonsumsi daging kuda akan memutuskan untuk mengkonsumsi daging kuda dengan jumlah yang berbeda.

Nilai R square sebesar 0,670 hal ini berarti bahwa nilai sebesar $67,0 \%$ adalah responden mengkonsumsi daging kuda dipengaruhi oleh variabel - variabel yang dipilih, sedangkan sisanya 33,0\% dipengaruhi faktor lainnya yang tidak diamati dalam penelitian ini.

Berdasarkan uji $\mathrm{F}$, dengan tingkat signifikan yang diperoleh lebih kecil yakni sebesar 0,000 dari standar signifikan yakni 0,05 . Perbandingan antara $F$ hitung dan $F$ tabel dimana $\mathrm{F}$ hitung sebesar 1,899 lebih kecil dari $\mathrm{F}$ tabel yakni 16,054 maka dapat disimpulkan bahwa secara bersama-sama jenis kelamin, umur, pendidikan, pekerjaan, pendapatan, harga, jumlah anggota, barang subsitusi, suku, alasan dan selera berpengaruh signifikan terhadap konsumsi daging kuda. 
Persamaan regresi dari hasil ini dapat digambarkan sebagai berikut:

$$
\begin{gathered}
y=-0,8752+0,099 x_{1}+0,020+0,170 x_{3}+0,194 x_{4}+0,00000005075 x_{5}+0,000005046 x_{6}+ \\
0,068 x_{7}+0,039 x_{8}-0,141 x_{9}-0,049 x_{10}+0,411_{x 11}
\end{gathered}
$$

\section{KESIMPULAN}

Hasil penelitian dan pembahasan, dapat disimpulkan bahwa faktor yang mempengaruhi konsumsi daging kuda di Kecamatan Doloksanggul kabupaten Humbang Hasundutan Sumatera Utara antara lain umur, pendidikan, pendapatan, jenis kelamin, pekerjaan, jumlah anggota, barang subsitusi dan selera berpengaruh positif. Suku dan alasan mengkonsumsi daging kuda berpengaruh secara negatif terhadap keputusan mengkonsumsi daging kuda. Secara bersama - sama jenis kelamin, umur, pendidikan, pekerjaan, pendapatan, harga, jumlah anggota, barang subsitusi, suku, alasan dan selera berpengaruh signifikan terhadap konsumsi daging kuda.

\section{DAFTAR PUSTAKA}

BPS. 2014. Humbang Hasundutan dalam angka. Badan Pusat Statistik. Humbang Hasundutan.

Hadiyanto. 2007. Komunikasi pembangunan dan pemberdayaan : Kasus pada peternakan rakyat. Sodality: Jurnal Sosiologi Pedesaan. 1(3):321-344.

doi:http://dx.doi.org/10.22500/sodality.v1i 3.5901

Hikmah. 2003. Karakteristik fisik, kimia dan organoleptik daging kuda di Sulawesi Selatan. Tesis. Program Pacasarjana, Institut Pertanian Bogor, Bogor.

https://humbahasnews.wordpress.com/2012/0 2/27/asal-mula-nama-dolok-sanggul/

Kadir, S. 2006. Analisis permintaan dan efisiensi penggunaan sumber daya dalam rangka meningkatkan produksi ternak kuda di Sulawesi Selatan. Lembaga Penelitian Universitas Hasanuddin. Makassar.
Kadir, S. 2011. Preferensi konsumen terhadap hasil olahan daging kuda di Makassar. Jurnal Agribisnis. X (3): 4957

Lawrie. R. A. 2003. Ilmu Daging. Jakarta: Penerbit Universitas Indonesia.

Parakkasi, A. 2006. Ilmu nutrisi dan makanan ternak monogastrik Volume IB. Jakarta: Penerbit Universitas Indonesia.

Purba, R. J. 2012. Produksi Karkas dan non karkas kuda sandel dan sumbawa jantan yang dipotong di Segoroyoso, Pleret, Bantul. Skripsi. Fakultas Peternakan. Universitas Gadjah Mada. Yogyakarta.

Riduwan. 2005. belajar mudah penelitian untuk guru, karyawan dan peneliti pemula. Bandung : Alfabeta.

Soeparno. 1998. Ilmu dan Teknologi Daging. Yogyakarta: Gajah Mada University Press.

Tim Karya Tani Mandiri. 2010. Pedoman Budidaya Beternak Kuda: Seri Budidaya Ternak. Bandung: CV. Nuansa Aulia

Uptreninfo. 2012. Manfaat asam amino bagi tubuh. (http://uptreninfo.com/manfaatasam-amino-bagi-tubuh, Diakses 15 November 2015).

Hotabilatdur, W. L., T. Supriana, dan Salmiah. 2013. Beberapa faktor yang mempengaruhi permintaan daging kuda (Kasus: Kecamatan Doloksanggul, Kabupaten Humbang Hasundutan). Journal of Agriculture and Agribusiness Socioeconomics, 2(4): 1-10. 